\title{
PENINGKATAN MOTIVASI BELAJAR MAHASISWA UNIVERSITAS INDRAPRASTA PGRI MELALUI QUANTUM TEACHING
}

\author{
Miftahly Nurrokhim \\ Dosen Program Studi Pendidikan Ekonomi Universitas Indraprasta PGRI \\ Email: trainermiftah@gmail.com
}

\begin{abstract}
Abstrak
Penelitian ini bertujuan untuk meningkatkan motivasi belajar mahasiswa Universitas Indraprasta PGRI melalui quantum teaching. Adapun penelitian ini dilaksanakan di Universitas Indraprasta PGRI. Penelitian ini menggunakan metode penelitian tindakan, yang dilaksanakan dalam 2 siklus. Teknik pengumpulan data yang digunakan dalam penelitian ini adalah angket dan wawancara. Teknik analisis data yang digunakan meliputi analisis data dengan statistika deskriptif dan analisis data secara kualitatif. Hasil penelitian menunjukkan bahwa mahasiswa dengan motivasi belajar tinggi mencapai $82 \%$. Dengan demikian dapat disimpulkan bahwa motivasi belajar mahasiswa Universitas Indraprasta PGRI dapat ditingkatkan melalui quantum teaching.

Kata kunci: Motivasi belajar, quantum teaching
\end{abstract}

\section{PENDAHULUAN}

Setiap manusia yang hidup di dunia ini membutuhkan pendidikan. Menurut Syah (2010: 10), pendidikan ialah sebuah proses dengan metode-metode tertentu sehingga manusia memperoleh pengetahuan, pemahaman, dan cara bertingkah laku sesuai dengan kebutuhan.

Dalam dunia kampus, proses pembelajaran harus membangun interaksi yang baik antara dua komponen, yaitu dosen dan mahasiswa. Interaksi yang baik dapat digambarkan dengan suatu keadaan dimana pendidik (dosen) dapat membuat peserta didik (mahasiswa) belajar dengan mudah dan terdorong untuk mempelajari materi pembelajaran.

Dalam standar proses pendidikan, pembelajaran menempatkan peserta didik sebagai subjek yang berorientasi pada aktivitas peserta didik. Seperti yang dikemukakan pada PP No. 19 Tahun 2005, bahwa: "proses pembelajaran pada satuan pendidikan diselenggarakan secara interaktif, inspiratif, menyenangkan, menantang, memotivasi peserta didik untuk berpartisipasi aktif, serta memberikan ruang yang cukup bagi prakarsa, kreativitas, dan kemandirian sesuai dengan bakat, minat, dan perkembangan fisik serta psikologis peserta didik". Dari Peraturan Pemerintah di atas tampak bahwa pembelajaran bukan sekedar penyampaian pengetahuan dari pendidik (dosen) ke peserta didik (mahasiswa), 
tetapi sebagai proses menciptakan lingkungan belajar yang dapat memfasilitasi peserta didik berpartisipasi aktif untuk mencapai hasil belajar.

Usaha yang dilakukan oleh seorang pendidik agar peserta didiknya mendapat hasil belajar yang baik, sangat dipengaruhi oleh faktor internal dan eksternal peserta didik sendiri. Syah (2010: 129) mengemukakan faktor-faktor yang dapat mempengaruhi proses dan hasil belajar pada peserta didik ada dua, yaitu faktor internal dan faktor eksternal. Faktor internal adalah faktor yang ada dalam diri peserta didik itu sendiri, yakni tingkat kecerdasan peserta didik, kemampuan awal, sikap, bakat, minat dan motivasi peserta didik. Sedangkan faktor eksternal adalah faktor yang berasal dari luar diri peserta didik, yaitu keadaan keluarga, kurikulum, metode mengajar dan sarana dan prasarana. Untuk mencapai hasil optimal, maka faktor internal dan eksternal tersebut perlu diupayakan dengan sebaik-baiknya.

Motivasi memerankan peranan yang penting, khususnya berpengaruh kuat terhadap tinggi rendahnya prestasi belajar mahasiswa. Pada saat kegiatan pembelajaran mahasiswa tidak hanya sekedar duduk diam, memperhatikan dan mencatat penjelasan dosen. Mahasiswa dituntut untuk berpikir, bertanya hal-hal yang belum dimengerti, memberikan pendapat, menjawab pertanyaan dosen maupun mahasiswa lain, bahkan mengkritik pendapat dosen maupun rekannya. Mahasiswa juga perlu terlibat secara emosional dalam belajar, memahami adanya masalah yang dihadapinya dan berusaha mencari solusi pemecahannya.

Begitu pula dalam pembelajaran mata kuliah Ilmu Alamiah Dasar, efektivitas pembelajaran dapat diraih apabila dosen mampu membangkitkan motivasi belajar mahasiswanya. Namun kenyataannya saat ini, hal itu belum mampu terlaksana dikarenakan pembelajaran mata kuliah Ilmu Alamiah Dasar masih banyak terdapat permasalahan. Salah satu permasalahan dalam pembelajaran mata kuliah Ilmu Alamiah Dasar adalah penerapan metode yang kurang tepat dan kurang bervariatif. Pada saat berlangsungnya proses pembelajaran mata kuliah Ilmu Alamiah Dasar dosen masih menerapkan metode pembelajaran yang monoton yaitu ceramah. Dimana dosen menerangkan, mahasiswa mendengarkan apa yang disampaikan dosen hingga proses belajar mengajar berakhir tanpa ada kesempatan untuk mengembangkan daya kreatifitas yang dimiliki mahasiswa. Dengan kondisi seperti itu menyebabkan proses 
pembelajaran kurang kondusif, membosankan, menjenuhkan, serta membuat motivasi belajar mahasiswa menurun.

Hasil observasi pada pembelajaran mata kuliah Ilmu Alamiah Dasar menunjukkan bahwa dosen masih menggunakan paradigma teacher center dalam mengajar. Dosen lebih banyak melakukan ceramah pada kegiatan pembelajaran. Pendekatan belajar seperti ini mengakibatkan mahasiswa kurang memiliki motivasi belajar dan hasil belajar mahasiswa yang rendah.

Berdasarkan hasil wawancara yang dilakukan terhadap beberapa mahasiswa, diperoleh informasi bahwa fakor penyebab kurangnya motivasi belajar mahasiswa yaitu penggunaan metode pembelajaran yang kurang tepat dan kurang variatif sehingga pembelajaran menjadi kurang bermakna dan peran dosen terlalu monoton sehingga mahasiswa tidak aktif terlibat dalam proses pembelajaran.

Kenyataan ini akan menjadi semakin serius apabila tidak segera diatasi. Upaya untuk mengatasi masalah tersebut adalah dengan meningkatkan motivasi belajar mahasiswa dalam pembelajaran mata kuliah Ilmu Alamiah Dasar melalui penerapan model pembelajaran Quantum Teaching, sehingga hasil belajar yang diharapkan pun akan tercapai.

\section{TINJAUAN PUSTAKA}

\section{Motivasi Belajar}

Motivasi biasanya didefiniskan sebagai keadaan internal yang membangkitkan, mengarahkan, dan mempertahankan perilaku (Woolfolk, 2009: 186) artinya motivasi merupakan suatu hal yang penting dalam berperilaku dan mencapai suatu tujuan. Definisi tersebut senada dengan yang dikemukakan Slavin (2011: 99), bahwa motivasi adalah sesuatu yang menyebabkan seseorang melangkah, membuat seseorang tetap melangkah, dan menentukan ke mana seseorang mencoba melangkah. Tanpa motivasi seseorang akan sulit atau bahkan tidak akan bisa mencapai tujuannya. Dengan memiliki motivasi yang besar seseorang bisa dapat terarah dalam proses pencapaian tujuan dan tidak akan mudah menyerah walaupun banyak hambatan yang menghadang.

Dalam kegiatan belajar, motivasi dapat dikatakan sebagai keseluruhan daya penggerak di dalam diri peserta didik yang menimbulkan kegiatan belajar, 
yang menjamin kelangsungan dari kegiatan belajar yang memberikan arah pada kegiatan belajar, sehingga tujuan belajar yang dikehendaki dapat tercapai.

Motivasi merupakan hal yang penting dalam belajar. Motivasi belajar merupakan suatu proses tingkah laku yang bersumber dari dalam diri individu yang terarah pada suatu tujuan belajar. Motivasi belajar akan dapat mengembangkan aktivitas dan dapat mengarahkan serta memelihara kegiatan belajar. Dalam belajar, motivasi berperan sebagai penumbuh gairah, merasa senang dan semangat untuk belajar. Dengan demikian motivasi dalam proses pembelajaran sangat dibutuhkan untuk terjadinya percepatan dalam mencapai tujuan pembelajaran dan pendidikan. Jadi, motivasi belajar merupakan sesuatu keadaan yang terdapat pada diri seseorang individu dimana ada suatu dorongan untuk melakukan kegiatan belajar guna mencapai tujuan.

A.M., Sardiman (2010: 82) mengemukakan beberapa fungsi motivasi di antaranya; Pertama, mendorong manusia untuk berbuat, jadi sebagai penggerak atau motor yang melepaskan energi. Dalam hal ini motivasi sebagai motor penggerak dari setiap kegiatan yang akan dikerjakan. Jadi, motivasi belajar berfungsi sebagai penggerak tingkah laku mahasiswa untuk belajar. Besar kecilnya motivasi akan menentukan cepat atau lambatnya suatu pembelajaran.

Kedua, menentukan arah perbuatan, yakni ke arah tujuan yang akan dicapai. Dengan demikian motivasi dapat memberikan arah dan kegiatan yang harus dikerjakan sesuai dengan rumusan tujuannya. Jadi, fungsi motivasi belajar sebagai penggerak tingkah laku $\mathrm{m} \mathrm{a} \mathrm{h}$ a siswa untuk belajar secara terarah dengan antusiasme mengikuti proses pembelajaran demi prestasi belajarnya.

Ketiga, menyeleksi perbuatan, yakni menentukan perbuatan-perbuatan apa yang harus dikerjakan yang serasi guna mencapai tujuan. Dengan menyisihkan perbuatan-perbuatan yang tidak bermanfaat bagi tujuan tersebut. Dengan fungsi ini, $\mathrm{m}$ a h a siswa dapat mencapai prestasi belajarnya dengan cara fokus dalam mengikuti pembelajaran dan menyampingkan hal-hal yang tidak bermanfaat seperti, bersenda gurau, melakukan aktivitas lain, dan tidak menghiraukan pelajaran yang disampaikan oleh dosen. 
Meece \& McColskey (2001: 18) menjelaskan beberapa indikator mahasiswa dengan motivasi tinggi, yaitu kehadiran dan disiplin, partisipasi dan penyelesaian pekerjaan, tekun dan gigih, kualitas pekerjaannya dalam tugas, dapat belajar secara mandiri, ketertarikan dan keinginan. Berdasarkan indikator motivasi menurut ahli, maka dapat disimpulkan bahwa mahasiswa yang memiliki motivasi belajar tinggi yaitu antusias, taat, tekun, ulet, dan mandiri.

\section{Quantum Teaching}

Menurut De Porter (2010: 34), quantum teaching adalah penggubahan bermacam-macam interaksi yang ada di dalam dan segurur momen belajar. Interaksi-interaksi ini mencakup unsur-unsur untuk belajar efektif yang mempengaruhi kesuksesan mahasiswa.

Dalam praktek, Quantum Teaching bersandar pada prinsip utama; "Bawalah Dunia Mereka ke dalam Dunia Guru (Pengajar, pendidik), dan Antarkan Dunia Guru (Pengajar, pendidik) ke dalam Dunia Mereka”. Setiap bentuk interaksi dengan peserta didik, setiap rancangan kurikulum, dan setiap metode pembelajaran harus dibangun di atas prinsip utama tersebut.

Ada enam langkah penting yang terkandung dalam kerangka rancangan quantum teaching yaitu TANDUR (De Porter, 2010: 39-40) (1) Tumbuhkan. Pada langkah ini dosen menuturkan sebuah cerita menarik dalam kehidupan yang dapat menumbuhkan semangat belajar mahasiswa. (2) Alami. Pada langkah ini dosen menciptakan pengalaman umum kepada mahasiswa, yang dapat dipahami oleh setiap mahasiswa(3) Namai. Dosen memberikan petunjuk dan kesempatan kepada mahasiswa untuk memberikan penamaan terhadap pengalaman belajar berkelompok yang telah diperolehnya (4) Demonstrasikan. Dosen menyediakan kesempatan bagi mahasiswa untuk menunjukkan (mendemonstrasikan) bahwa mereka tahu. (5) Ulangi. Dosen mengajak mahasiswa menyimpulkan garis besar materi pembelajaran yang telah dipelajari, memberikan warning dan stressing pada bagian-bagian materi yang dianggap sangat penting sebagai kata kunci dan memberikan tes formatif untuk mengetahui ketercapaian tujuan pembelajaran, dan (6) Rayakan. Dosen memberikan penghargaan kepada mahasiswa atau kelompok mahasiswa yang mendapatkan point terbanyak, menginformasikan tugas yang harus dikerjakan dirumah serta memberitahukan topik materi yang akan dipelajari pada pertemuan berikutnya. 


\section{METODE}

Metode yang digunakan dalam penelitian ini adalah penelitian tindakan (action research). Penelitian ini dilaksanakan di Universitas Indraprasta PGRI.

Desain penelitian ini mengacu pada apa yang dikemukakan oleh Kemmis dan Taggart yang dikutip dari Hopkins (1993: 48)

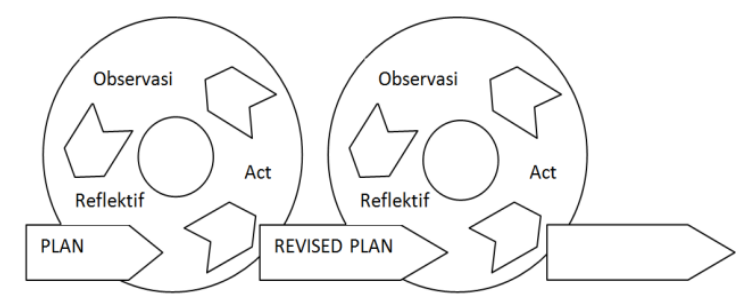

\section{Gambar 1. Model Penelitian Tindakan Kemmis dan Taggart}

Siklus pertama meliputi: (1) Perencanaan siklus pertama, (2) Tindakan, (3) Pengamatan, dan (4) Refleksi. Apabila belum mencapai indikator keberhasilan yang diharapkan, maka dilanjutkan ke siklus berikutnya.

Kriteria keberhasilan tindakan yang diharapkan pada penelitian ini adalah meningkatnya motivasi belajar mahasiswa. Penelitian tindakan ini dianggap berhasil apabila minimal $75 \%$ dari jumlah mahasiswa memiliki motivasi belajar kategori tinggi. Indikator motivasi tinggi yang digunakan dalam pengukuran penelitian ini berdasarkan teori motivasi dari para ahli yang penulis sintesiskan sebagai berikut. (a) Antusias, (b) Taat, (c) Tekun dalam menyelesaikan tugas, (d) Ulet menghadapi kesulitan, (e) Lebih senang belajar mandiri.

Teknik pengumpulan data yang digunakan dalam penelitian ini adalah angket dan wawancara.

Sebelum digunakan, angket diujicobakan terlebih dahulu untuk mengetahui validitas dan menghitung reliabilitasnya. Uji validitas dengan menggunakan rumus product moment Pearson. Adapun hasilnya dari 38 butir pertanyaan angket motivasi belajar didapat item yang valid berjumlah 33 butir (1, $2,3,5,6,7,8,10,11,12,13,14,15,17,18,19,20,21,22,23,24,25,26,27,28$, $30,31,32,34,35,36,37,38)$. Kemudian untuk mengetahui nilai reliabilitasnya dengan rumus alpha Cronbach. Dari hasil ujicoba angket motivasi, nilai reliabilitasnya 0,912 , termasuk kategori reliabilitas sangat tinggi.

Teknik wawancara dilakukan secara terbuka, artinya mahasiswa tahu bahwa mereka sedang diwawancarai dan mengetahui pula apa maksud wawancara 
tersebut. Wawancara juga berdasarkan pertanyaan yang tidak terbatas (tidak terikat) jawabannya. Wawancara dalam penelitian ini dilakukan secara informal di luar jam pelajaran.

Untuk memperoleh data yang dapat dipercaya kebenarannya, maka dilakukan uji kredibilitas terhadap data yang terkumpul dengan mempergunakan teknik triangulasi data. Maksudnya membandingkan data hasil wawancara dengan data hasil pengamatan, membandingkan apa yang dikatakan orang di depan umum dengan apa yang dikatakan secara pribadi.

Teknik analisis data yang digunakan meliputi analisis data dengan statistika deskriptif dan analisis data secara kualitatif. Analisis data dengan statistika deskriptif disajikan dalam bentuk tabel atau grafik. Analisis secara kualitatif dilakukan dengan cara mendeskripsikan informasi yang digunakan sebagai data selama pengumpulan data dan setelah data terkumpul. Analisis selama pengumpulan data meliputi mengembangkan catatan lapangan.

\section{HASIL PENELITIAN DAN PEMBAHASAN}

\section{Hasil Tindakan Siklus I}

Peningkatan motivasi belajar mahasiswa berdasarkan data angket motivasi yang diperoleh pada siklus I, dapat dilihat pada gambar berikut.

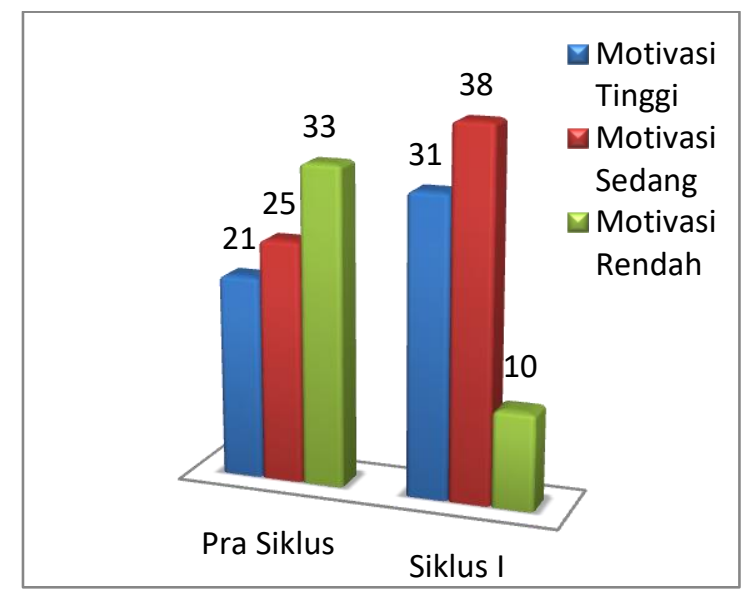

Gambar 2. Grafik Peningkatan Motivasi Belajar Mahasiswa Universitas Indraprasta PGRI Siklus I

Penerapan model quantum teaching untuk meningkatkan motivasi belajar mahasiswa Universitas Indraprasta PGRI pada siklus I belum mencapai indikator keberhasilan (minimal $75 \%$ dari jumlah mahasiswa memiliki motivasi belajar kategori tinggi), yaitu hanya mencapai 39\% dari jumlah mahasiswa yang memiliki 
motivasi belajar kategori tinggi. Refleksi penerapan model quantum teaching pada siklus I yaitu:

1. Dosen belum memotivasi mahasiswa secara optimal melalui apersepsi, mengaitkan materi pembelajaran dengan kehidupan sehari-hari mahasiswa dan menyampaikan berbagai informasi yang berhubungan dengan materi yang diajarkan.

2. Pada saat menamai konsep, dosen masih menggunakan kata-kata saja, sehingga mahasiswa membutuhkan waktu lama untuk memahaminya.

3. Dosen belum mengoptimalkan suasana belajar yang dapat membuat mahasiswa termotivasi untuk belajar.

4. Dosen belum memperhatikan mahasiswa secara secara menyeluruh.

5. Dosen belum melibatkan seluruh mahasiswa secara aktif dalam pembelajaran.

6. Penerapan model quantum teaching pada mata kuliah Ilmu Alamiah Dasar dalam upaya meningkatan motivasi belajar mahasiswa belum dapat diterapkan secara optimal.

\section{Revisi}

Berdasarkan data hasil motivasi belajar mahasiswa yang belum mencapai kriteria keberhasilan tindakan, maka perlu dilakukan revisi tindakan untuk memperbaiki proses pembelajaran.

Revisi terhadap kekurangan hasil motivasi mahasiswa antara lain yaitu (1) perlu adanya motivasi dan bimbingan pada mahasiswa yang kurang motivasi agar lebih giat dalam mengikuti pembelajaran mata kuliah Ilmu Alamiah Dasar (2) Dosen menambahkan cara-cara memotivasi mahasiswa dalam pembelajaran yaitu dengan memberikan penghargaan kepada kelompok yang aktif dalam pembelajaran dengan memberikan tanda bintang (3) Dosen perlu mengoptimalkan suasana belajar yang menyenangkan sehingga dapat membuat mahasiswa termotivasi untuk belajar, dengan memberikan fun games sebelum pembelajaran dimulai.

\section{Hasil Tindakan Siklus II}

Peningkatan motivasi belajar mahasiswa berdasarkan data yang diperoleh pada siklus II, dapat dilihat pada gambar berikut. 


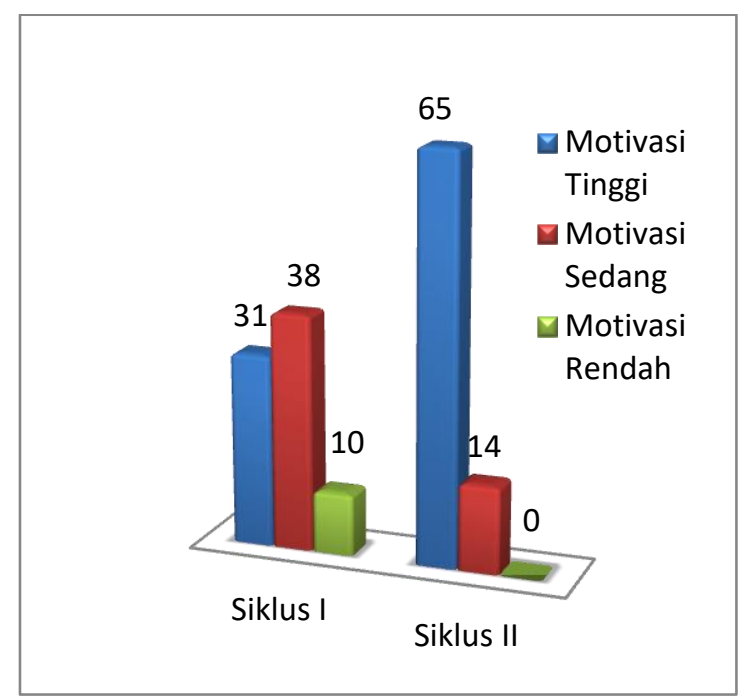

Gambar 3. Grafik Peningkatan Motivasi Belajar Mahasiswa Universitas Indraprasta PGRI Siklus II

Dari paparan hasil angket motivasi mahasiswa siklus II, menunjukkan sudah terpenuhinya kriteria keberhasilan tindakan, yaitu persentase mahasiswa dengan motivasi tinggi sudah mencapai kriteria keberhasilan, yaitu $82 \%$ dari jumlah mahasiswa yang memiliki motivasi belajar kategori tinggi. Hal ini dikarenakan penerapan model quantum teaching dalam pembelajaran mata kuliah Ilmu Alamiah Dasar sudah dilaksanakan secara optimal sehingga mampu memotivasi mahasiswa dan menciptakan suasana belajar yang dapat membuat mahasiswa termotivasi untuk belajar.

Pada siklus II motivasi belajar mahasiswa telah mencapai kriteria keberhasilan. Keberhasilan dari motivasi belajar mahasiswa pada tindakan siklus II disebabkan oleh beberapa faktor antara lain sebagai berikut:

a) Dosen sudah optimal memotivasi dan membimbing mahasiswa yang kurang motivasi agar lebih giat dalam mengikuti pembelajaran mata kuliah Ilmu Alamiah Dasar.

b) Dosen sudah mengoptimalkan suasana belajar yang menyenangkan seperti memberikan fun games dan senam otak sebelum pembelajaran dimulai.

c) Dosen memotivasi mahasiswa dengan memberikan penghargaan berupa tanda bintang kepada kelompok yang berani demonstrasi sehingga kelompok lain termotivasi untuk melakukan demonstrasi. 
Berdasarkan paparan data motivasi belajar mahasiswa pada siklus II, maka penelitian tindakan tidak perlu dilanjutkan ke siklus berikutnya karena sudah memenuhi kriteria keberhasilan tindakan.

Keberhasilan penelitian tindakan dalam meningkatkan motivasi belajar mahasiswa Universitas Indraprasta PGRI dapat digambarkan pada grafik berikut.

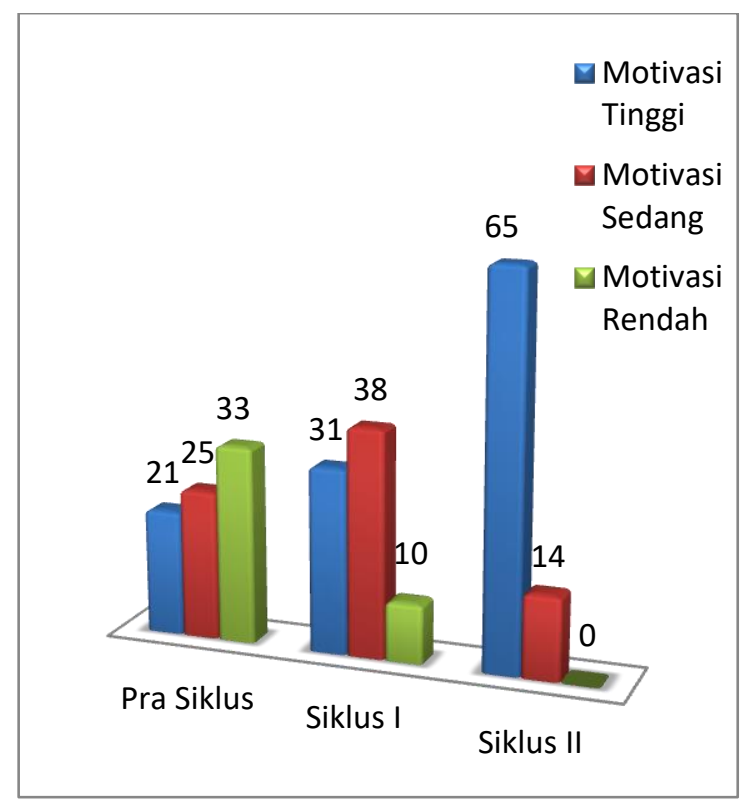

Gambar 4. Grafik Rangkuman Peningkatan Motivasi Belajar Mahasiswa Universitas Indraprasta PGRI

\section{SIMPULAN}

Penelitian ini menghasilkan kesimpulan bahwa penerapan model quantum teaching pada mata kuliah Ilmu Alamiah Dasar di Universitas Indraprasta PGRI terbukti dapat meningkatkan motivasi belajar mahasiswa.

Berdasarkan kesimpulan penelitian di atas yang menjadi implikasi penelitian ini adalah sebagai berikut. Pertama, jika dosen akan menerapkan model quantum teaching untuk meningkatkan motivasi belajar dalam pembelajaran, maka harus memperhatikan karakteristik materi pembelajaran, karakteristik mahasiswa, sarana dan prasarana, alokasi waktu pembelajaran, dan kondisi kelas.

Kedua, dalam penerapannya model quantum teaching membutuhkan kemampuan berpikir kritis dan nalar dalam melakukan tahapan Tumbuhkan, Alami, Namai, Demostrasikan, Ulangi dan Rayakan (TANDUR), sehingga model ini sesuai untuk siswa kelas tinggi ataupun mahasiswa. 
Research and Development Journal Of Education

Vol. 5 No. 1 Oktober 2018

ISSN 2406-9744

\section{DAFTAR PUSTAKA}

A.M, Sardiman. InteraksidanMotivasi Belajar Mengajar. Jakarta: Rajawali Pers, 2011.

Anderson, L. W., \& Krathwohl, D. R. (Eds.). 2001.A Revision of Bloom's Taxonomy of Educational Objectives. New York : Longman

DePorter, Bobbi. 2010. .Quantum Teaching: Mempraktikkan Quantum Learning di Ruang-Ruang Kelas. Bandung: Kaifa

Hopkins, David. 1993. A Teacher's Guide to Classroom Research. Buckingham: Open Universiti Press,

Meece, Judith \& McColskey,Wendy. 2001. Improving Student Motivation: A Guide for Teachers and School Improvement Teams.Carolina: SERVE

PP No. 19 Tahun 2005 Tentang Standar Nasional Pendidikan

Slavin, Robert E. 2011. Psikologi Pendidikan Teori dan Praktik. Jakarta: PT. Indeks

Sudjana, Nana. 2010. Dasar-dasar Proses Belajar Mengajar. Bandung: Sinar Baru Algesindo

Sudjana, Nana. 2010. Dasar-dasar Proses Belajar Mengajar. Bandung: Sinar Baru Algesindo

Syah, Muhibbin. 2010. Psikologi Pendidikan dengan Pendekatan Baru. Bandung: PT. Remaja Rosdakarya

Woolfolk, Anita. 2009. Educational Psychology Active Learning Edition. Yogyakarta: Pustaka Pelajar 